\title{
EXTERNAL CONDITIONS OF THE PROCESS OF SHAPING THE DYNAMICS OF ECONOMIC GROWTH*
}

\author{
Andrzej Szopa** (D) https://orcid.org/0000-0001-5193-3861
}

\begin{abstract}
This study attempts to determine how external factors affect economic growth. It is a methodological solution unique in the literature enabling the study of basic contemporary phenomena associated with globalisation. The advantage of the proposed solutions is their transparency and simplicity. The introduction of two types of membranes is of key importance. The presented model creates great opportunities for its development and verification of the adopted solutions in the long run.
\end{abstract}

Keywords: membrane, credit instruments (CDS), market interest rate, Economic Value Added (EVA), demonstration effect, Veblen effect, Giffen effect, SEDA indicator

\section{JEL Codes: E27}

Contemporary management conditions are characterised by the growth of internalisation processes arising from an ever-deepening globalisation. This is overlapped by technological progress which facilitates financial settlements on an international scale. These phenomena impose the need to take into account the factor of external conditions in the research on economic growth. In this study this problem was solved by the concept of two membranes: internal and external. The essence of this solution is to use the feature of the membrane, i.e. a selective partition between two spheres limiting the flow of funds only to those that have the appropriate features. As a result, pressure is equalised on both sides of the membrane. It follows that if the membrane does not meet this condition then the flow of funds remains stipulated.

\footnotetext{
* This article is a development of the theses contained in: Szopa, 2017.

** Jagiellonian University (a retired professor). E-mail: uuszopa@cyf-kr.edu.pl
} 


\section{THE ESSENCE OF THE OUTER MEMBRANE}

The outer membrane separates two environments: external (international financial market) and internal (domestic financial market). ${ }^{1}$ It was decided to describe each area in the following financial categories: credit default swap (CDS) ${ }^{2}$ and domestic market interest rate $(r){ }^{3}$ The CDS interest rate (i.e. the cost of CDS) sets the level of the interest rate for domestic debt on the international market, i.e. it sets the cost of financing domestic debt from international funds. Comparing the interest rates in the internal market, you can choose the sources of financing for the needs of the national budget. The membrane's role - in the absence of restrictions on capital flows - is to equalize the CDS interest rates and the country's market interest rate. ${ }^{4}$ The appearance of any impediments to capital flow (such as administrative restrictions, institutional barriers) causes that this process is distorted. The effect is a discrepancy in the cost of financing between the domestic and international market. As a result, there is a distortion of the optimal cost of business operation financing.

\section{THE SIGNIFICANCE OF THE INTERNAL MEMBRANE}

The internal membrane separates the sphere of the national interest rate (r) and return on assets (ROA). Thus, it is an instrument that separates the domestic financial market (r) from the sphere of production (ROA) or in other words national sources of financing and production activity. The relationship (difference) between the market interest rate and the rate of return on assets determines the efficiency of the investment process (EVA) and ensures optimal

1 We are talking about financial terms because financial categories are the best medium of contact between various spheres.

2 CDS is an instrument that is very sensitive to any manifestation of the country's insolvency risk. This risk is a function of the country's payment difficulties, which include: delays in debt repayment, irregular fulfillment of obligations and eventually cessation of meeting the obligations.

3 The domestic market interest rate is the effect of a given country's monetary policy and thus it concerns a certain range of independence (freedom) in shaping its level.

4 The domestic market interest rate increases as the financing from domestic sources increases (pushing effect). Equating both interest rates ensures a balance between the sources of funding. 
selection of effective investment projects. ${ }^{5}$ On the one hand, it allows us to distinguish the divestment process when EVA is negative and thus the investment activity is ineffective and the investment process under which making investments is fully justified and effective. Thus, the relationship between the economic value added (EVA) determines economic growth dynamics and at the same time economic recession. ${ }^{6}$

\section{THE IMPACT OF THE LEVEL OF SAVINGS RATE ON THE COURSE OF ECONOMIC GROWTH ${ }^{7}$}

The level of savings determines the tensions between consumption and investments. The increase in the savings rate reduces the pressure on the interest rate increase and, conversely, the decrease in savings results in a decrease in the pressure on the increase in the savings rate. Let us assume the residual nature of savings in relation to consumption (Sztaudynger, 2007).

The following factors determine the level of consumption and thus the possibility of its reduction:

- The existing level of consumption. The lower it is, the stronger will be society's resistance to its reduction.

- Household diversity. The greater the diversity of the material situation, the easier it may be to reduce consumption, primarily as a result of a stronger reduction in the material situation of better-off groups and social strata.

- Demonstration effect. The effect of the demonstration consists in the pursuit of the less affluent to imitate the consumption of higher-income groups and as a result higher consumption.

- Bolt effect - means the pursuit of all groups and layers to defend the level of consumption achieved so far.

- Veblen paradox - concerns the changes in consumption due to changes of the prices of luxury goods.

- Giffen paradox - describes how consumption changes under the influence of changes in the prices of basic consumer goods.

\footnotetext{
5 The difference between return on assets (ROA) and the cost of capital (in this case the market interest rate) is an excess of efficiency over the cost of capital.

$6 \quad$ It is generally accepted that investments are a carrier of value added provided a positive value of the ratio (EVA).

7 It is enough to quote here the key work of Kalecki (1960).
} 
- Veblen paradox - relates to changes in consumption due to changes in the prices of luxury goods.

- Deviation from the even development of society. The point here is that the individual factors determining social attitudes impact these attitudes with different force. ${ }^{8}$

These effects make it extremely difficult to freely shape the level of consumption and thus the structure of the gross domestic product distribution.

\section{ECONOMIC GROWTH MODEL}

The construction of the economic growth model involves the combination of both membranes. The factor which enables this procedure is that in both cases there is a category of the market interest rate. In the case of the outer membrane, the interest rate is subject to extortion from CDS interest rate, which indicates the cost of financing business processes from external sources.

In turn, the internal membrane forces the market interest rate level in the amount of the ROA ratio. We assume that as a result of interaction both rates should be equal for obvious reasons. ${ }^{9}$

In turn, the balance determined by the internal membrane establishes the relationship between the production sphere and the domestic financial market. The interest rate determines the level of the cost of capital raised compared to the efficiency of managing ROA and we move to the concept of Economic Value Added (EVA). A condition for undertaking the investment process (economic development) is to get a positive EVA ratio value. The dilemma - development or stagnation is determined by the mutual relationships between the said two values.

The synthetic form consists in eliminating the indirect link in the form of the interest rate and indicating the direct relationship between

\footnotetext{
8 This is implemented by the concept of the so-called SEDA. The SEDA index and its fluctuations are a resultant of detailed parameters: 1. Production volume (GDP), 2. Economic stabilisation (inflation and unemployment rate), 3. Level of employment (unemployment), 4. Quality of healthcare, 5. Level of average citizens' education, 6. Development of the social infrastructure, 7. Social diversity, 8. Development of civic society, 9. Relations of business entities with the central authority, 10. Environmental protection (SEDA, 2019). This ratio can be treated as a measure of the level of social development. This measure for Poland is 68.7, while it is the highest for Norway - 87.7.

9 Otherwise, we are dealing with classic arbitrage, which in the long run will lead to equalization of market interest rates.
} 
interest rate on credit default swap (CDS) and the efficiency of economic processes within the country (ROA). An equilibrium will occur when both parameters are equal and this is due to the fact that CDS determines the market level of interest rates (capital cost) and it should not be higher than the ROA ratio. This determines the effectiveness of the investment process and thus is a source of divestment or an effective investment process. In other words, this factor determines economic growth dynamics (Sobolewski, Wojtkowiak, 2014).

The obvious question is what does the presented model bring new to the theory of growth. In this case, one can limit the comments to the following:

1. The external factor was introduced by the interest rate on credit derivatives (it is a function of country risk).

2. The model takes into account the relationship between the domestic and international financial markets.

3 . The dynamics of economic growth were considered by including the Economic Value Added (EVA).

4. Two conditions were distinguished: economic recession and economic development.

\section{REFERENCES}

Kalecki, M. (1960). Zarys teorii wzrostu gospodarczego. Warszawa: PWN. SEDA (2019). An Interactive Guide. Boston Consulting Group.

Sobolewski, H. \& Wojtkowiak, G. (2014) Podejmowanie decyzji dezinwestycyjnych. Zeszyty Naukowe Uniwersytetu Szczecińskiego, 803; Finanse, Rynki Finansowe, Ubezpieczenia, 66.

Szopa, A. (2015). Czynniki ryzyka kraju (sovereign risk). In: A. Szopa, P. Zamora (eds.), Rola państwa w gospodarce w warunkach kryzysu - teoria i praktyka (pp. 81-94). Wrocław: Wydawnictwo eBooki.com.pl.

Szopa, A. (2017). Ryzyko źródeł finansowania długu publicznego. In: M. Thlon, R. Sieradzki, A. Szopa, Wybrane zagadnienia ryzyka na rynkach finansowych (pp. 111-137). Rzeszów: Innoreg.

Sztaudynger, J. (2007). Społeczne problemy wzrostu gospodarczego - analiza ekonometryczna. In: B. Klimczak, A. Lewicka-Strzałecka (eds.), Etyka i ekonomia (pp. 133-164). Warszawa: PTE. 


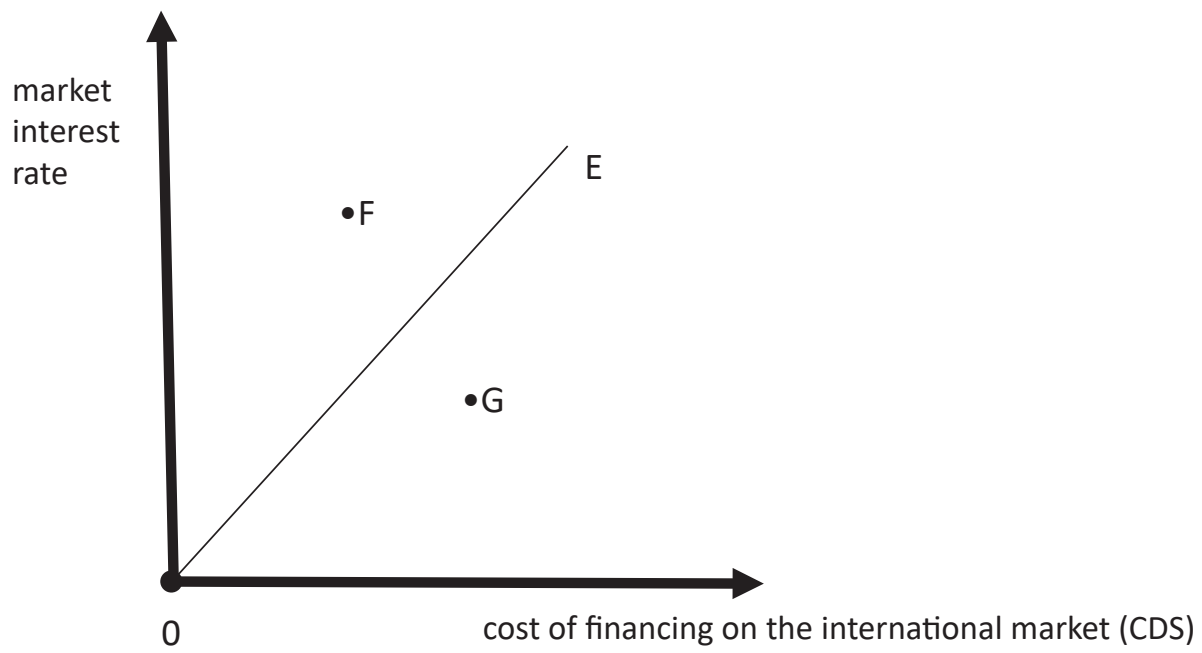

Legend: The straight line OE sets the balance between $\mathrm{r}$ (market interest rate - financing on the domestic market) and CDS (cost of financing on the international market). Point F - indicates the market situation, the interest rate (r) is higher than CDS. This indicates a higher cost of financing on the domestic market compared to the international market. Under conditions of full freedom of capital flows, this should gradually equalise the cost of financing on both markets. The opposite situation is described by point G. The higher cost of financing on international markets may result from the high level of country risk. The effect should be to reduce funding on international markets and increase funding in the domestic market, and ultimately the cost of financing on both markets should be gradually equalised. It should be remembered that the country risk is determined by difficulties in meeting international obligations. Ultimately, the cost of funding on international markets is determined by the relationships between the creditor countries and the debtor country. (A classic example may be Greece as a country which is an object of international support).

\section{Figure 1. Outer membrane operation}

Source: Author's own elaboration. 


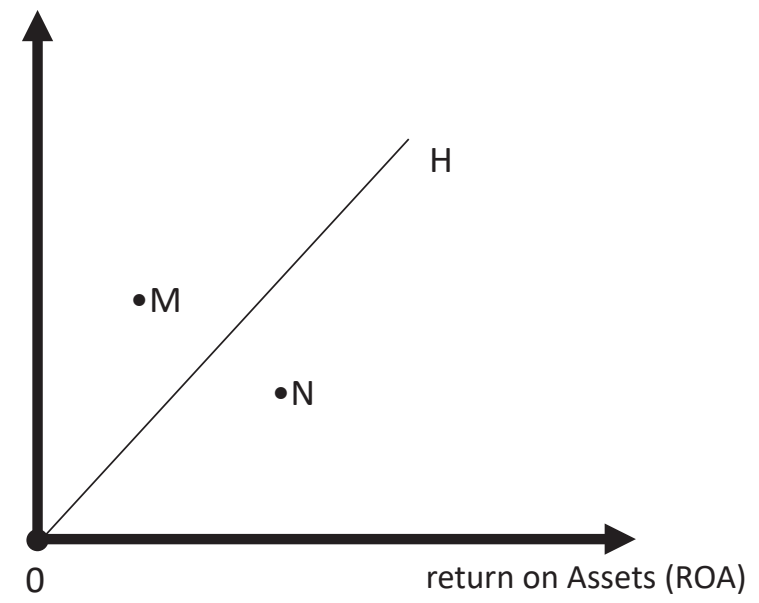

Legend: The straight line $\mathrm{OH}$ determines the balance between market interest rate $(\mathrm{r})$ and return on assets (ROA). This is because management efficiency (ROA) should cover the cost of capital employed (r). In other words, the condition for equality is ROS $=r$. Point M indicates a higher market interest rate than return on assets. This means that economic efficiency is not sufficient to finance the cost of capital. Investment activities are therefore not justified. This means that the investment activity must be limited in this way. In turn point $\mathrm{N}$ is the opposite situation. The cost of capital is lower than management efficiency, thus the investment process is fully justified. The following assumptions can be made here:

$\mathrm{r}>\mathrm{ROA}$ - the economy through divestments falls into stagnation processes

$r<$ ROA - thanks to effective investment process, we can expect economic growth

\section{Figure 2. The essence of the internal membrane}

Source: Author's own elaboration. 


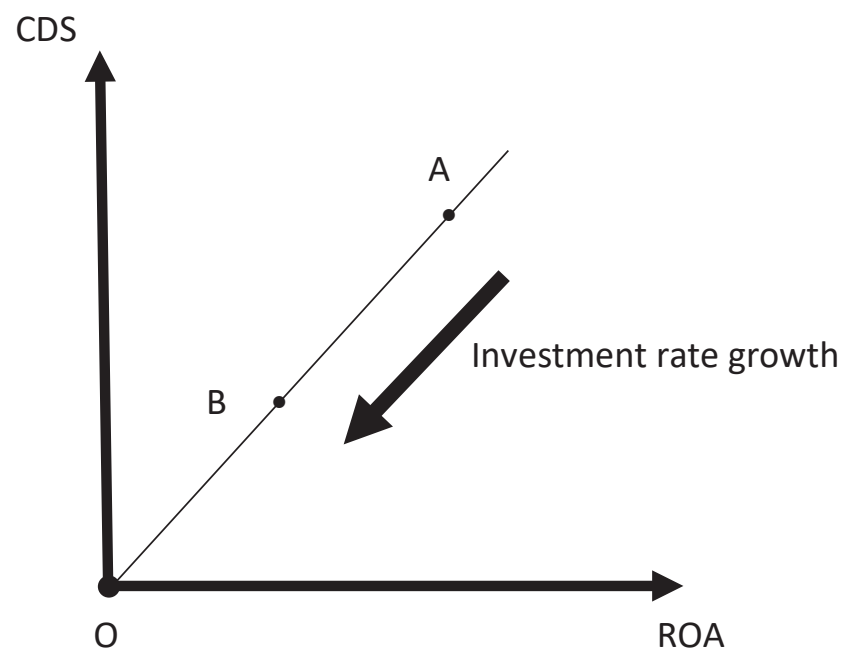

Legend: Investment rate increase reduces the tension between the sphere of consumption and investment activity. As a consequence, the increase in the amount of free funds (shifting from A to B) leads to a decrease in interest rates and thus, by increasing the EVA ratio, it allows for economic growth acceleration.

Figure 3. The impact of the investment rate on economic growth dynamics Source: Author's own elaboration. 


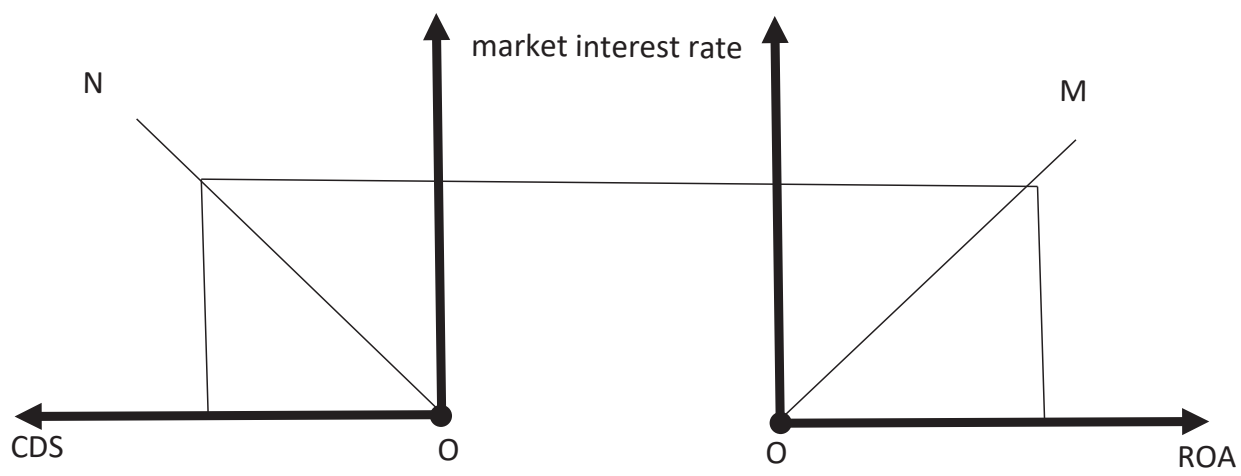

Legend: $\mathrm{ON}$ and $\mathrm{OM}$ lines characterise the equilibrium between the international financial market and the domestic financial market. The cash flows between the two markets lead to the equalisation of CDS and r. In turn, the OM line describes the state of balance between wthe production sphere (ROA) and the domestic financial market (r). Financing requirements for an effective investment process are causing both rates to oscillate around each other. If we assume that the initial impulse comes from the international financial market, the following relationship is created: CDS change. If we assume that the initial impulse comes from the international financial market, the following relationship is created: change in CDS $\rightarrow$ forcing the flow of the national interest rate $\rightarrow$ confronting the interest rate with management efficiency leads to either incentives for undertaking the investment process or limiting the volume of fixed assets (divestments). In other words, the final result is the shaping of the dynamics of economic growth.

Figure 4. Economic growth, analytical approach

Source: Author's own elaboration. 


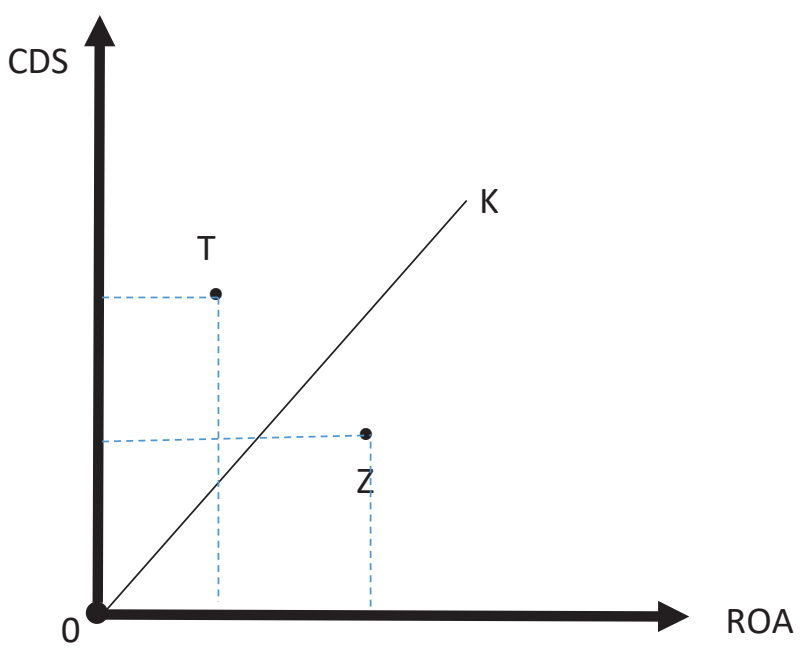

Legend: The OK line determines the balance between the international financial market and the domestic production sphere. Based on the considerations to date, it can be assumed that the points situated over the OK line describe the situation of economic recession (point T). Thus, the points situated under the OK line indicate the possibility of effective investment activity.

Figure 5. Economic growth, synthetic approach

Source: Author's own elaboration.

\section{ZEWNĘTRZNE UWARUNKOWANIA KSZTAKTOWANIA DYNAMIKI WZROSTU GOSPODARCZEGO}

\section{Abstrakt}

Za pomoca koncepcji membran wewnętrznej i zewnętrznej w opracowaniu wskazano na wzajemne uwarunkowana czynników kształtujących dynamikę procesów gospodarczych. Szczególne znaczenie przypisano warunkom zewnętrznym. Odpowiada to dominującym w ostatnim okresie w gospodarce globalizacji i internalizacji.

Słowa kluczowe: membrana, kredytowe instrumenty finansowe (CDS), rynkowa stopa procentowa, Ekonomiczna Wartość Dodana, efekt demonstracji, Efekt Veblena, Efekt Giffena, Wskaźnik SEDA 